MINI-SERIES

\title{
The importance of temporal heterothermy in bats
}

\author{
C. Stawski ${ }^{1,2}$, C. K. R. Willis ${ }^{3}$ \& F. Geiser ${ }^{2}$ \\ 1 Institute of Environmental Sciences, Jagiellonian University, Kraków, Poland \\ 2 Centre for Behavioural and Physiological Ecology, Zoology, University of New England, Armidale, NSW, Australia \\ 3 Department of Biology and Centre for Forest Interdisciplinary Research, University of Winnipeg, Winnipeg, Canada
}

\section{Keywords}

bat; chiroptera; disease; heterothermy; hibernation; reproduction; torpor; white-nose syndrome.

\section{Correspondence \\ Clare Stawski, Zoology, University of New England, Armidale, NSW 2351, Australia \\ Email: clare.stawski@gmail.com \\ Editor: Heike Lutermann}

Received 1 May 2013; revised 17 October 2013; accepted 4 November 2013

doi:10.1111/jzo.12105

\begin{abstract}
Animals must balance their energy budgets even when confronted with periodic food shortages and/or adverse environmental conditions. Especially, small endothermic animals require large amounts of energy to maintain high and stable body temperatures $\left(T_{\mathrm{b}}\right)$ via endogenous heat production. To deal with energetic challenges, many small endotherms are heterothermic, abandon regulation of high $T_{\mathrm{b}}$ and enter a state of torpor resulting in large energy savings. Torpor is used by many bat species because they are small, have high rates of heat loss and rely on fluctuating food resources (e.g. insects, fruit, nectar). Many bats use torpor all year, but the expression of temporal heterothermy can be strongly seasonal especially for temperate and subtropical species, which may hibernate for long periods. Recent advances in our understanding of torpor expression in bats have been made using temperature telemetry for remote data collection of $T_{\mathrm{b}}$ in free-ranging wild individuals from all climate zones. This new knowledge on free-ranging bats has revealed the importance of torpor expression not only for energy conservation but also for other benefits, such as reduction of extrinsic mortality (e.g. predation). On the contrary, dense clustering during hibernation, important for minimizing energy and water loss, may also expose bats to infectious disease. An emerging, cold-tolerant fungal pathogen of bats causes a new disease called white-nose syndrome (WNS), which is devastating populations of multiple species in eastern North America. Given the importance of temporal heterothermy to their biology, and links between torpor expression and mortality from WNS, it is becoming increasingly important to understand the ecology and physiology of torpor in this largely understudied and cryptic mammalian group. Here, we review past and current literature to summarize the importance and evolution of heterothermy in bats.
\end{abstract}

\section{Introduction}

Critical to any organism's survival and fitness is balancing energy acquisition and expenditure so all necessary functions of life and reproduction can be maintained. Inter-annual, seasonal and unpredictable changes in environmental conditions create challenges for both the intake and the expenditure sides of this energy budget (Nagy, Girard \& Brown, 1999; Tattersall et al., 2012). Cold winters and droughts can significantly reduce food availability, resulting in a mismatch between energy uptake and energy expenditure. As a result, selection has favoured a range of adaptations that help maintain energy balance in the face of changing environments. Endothermic animals benefit from the ability to remain active for energy acquisition across a broad range of conditions. However, they require large amounts of energy for heat production to regulate high and relatively stable body temperatures $\left(T_{\mathrm{b}}\right)$
(Speakman \& Thomas, 2003). Especially for small species with a large relative surface area, this energy use can exceed that of similar-sized ectotherms by $30-100$ times, especially at low ambient temperatures $\left(T_{\mathrm{a}}\right)$ (Nagy et al., 1999; Speakman \& Thomas, 2003). Many small mammals and birds therefore use torpor, also referred to as temporal heterothermy, which is a reduction of $T_{\mathrm{b}}$ and metabolic rate (MR) to conserve energy and also water (Ben-Hamo et al., 2013; Geiser, 2013). These mammals and birds are thus heterothermic endotherms that are capable of regulating a high $T_{\mathrm{b}}$, but are also able to thermo-conform over a wide temperature range (Speakman \& Thomas, 2003; Geiser, 2013).

Bats are one taxon that is especially likely to exhibit torpor. The vast majority of bat species are small and weigh $<25 \mathrm{~g}$ and nearly half weigh $<10 \mathrm{~g}$ (Willis, Turbill \& Geiser, 2005). Their high rates of heat loss to the environment due to small size are further exaggerated by their highly vascularized flight mem- 
branes (Lyman, 1970; Yalden \& Morris, 1975). As bats have high maintenance and thermoregulatory energy requirements together with the energetically expensive activities of flying and echolocation (Fenton, 1983; Neuweiler, 2000; Shen et al., 2010), they need to manage their energy prudently.

Although many bats tend to express torpor, they are likely to exhibit a range of thermoregulatory strategies, simply because they are so diverse (Table 1). With c. 1100 species, bats represent about $20 \%$ of mammalian species and are found in virtually all terrestrial ecosystems (Brunet-Rossinni \& Austad, 2004; Wilson \& Reeder, 2005; Monadjem et al., 2010; Wang, Walker \& Poon, 2011). Bats inhabit many climate zones, including highly seasonal cold-temperate and warm tropical climates, and roost in varying microclimates, from thermally stable caves to thermally unstable leaves (BrunetRossinni \& Austad, 2004; Kunz et al., 2011).

Depending on climate and roosts, patterns of temporal heterothermy vary among species (Table 1). Some species only appear capable of daily torpor (i.e. short and shallow bouts), whereas others hibernate during winter with the typical pattern of deep multi-day bouts of torpor interspersed by short periodic arousals (Geiser \& Ruf, 1995). The majority of bats inhabit warm climates and many of these express short bouts of torpor, although some species can hibernate (Geiser \& Stawski, 2011). The number of bats inhabiting temperate regions is much smaller and all of these species are exclusively insectivorous (Davis, 1970; Willig, Patterson \& Stevens, 2003; Geiser \& Stawski, 2011). While some temperate bats are known to migrate to avoid energetically demanding winters (Stones \& Wiebers, 1965; Davis, 1970; McGuire \& Boyle, 2013), most do not migrate long distances (i.e. $>500-1000 \mathrm{~km}$ ) but hibernate, some with extremely long bouts of torpor and very low $T_{\mathrm{b}}$ (Hock, 1951; Thomas \& Geiser, 1997; Speakman \& Thomas, 2003; Geiser, 2006; Jonasson \& Willis, 2012).

Metabolism and thermal physiology of normothermic and torpid bats are also influenced by body mass. As for all endotherms, large bats have lower mass-specific resting MRs at low $T_{\mathrm{a}}$ in comparison to small bats. However, even under thermo-neutral conditions, bats, particularly vespertilionids, have a lower basal MR than other mammals of similar size (McNab, 1982; Hosken \& Withers, 1997; Willis et al., 2005). The vast differences in body size and ecology of bats, among other factors, will result in differences in thermal energetics and torpor expression (Table 1).

Climate change already appears to be linked to the recent extinction of at least one bat species (i.e. the Christmas Island pipistrelle Pipistrellus murrayi; Martin et al., 2012). Along with global warming and habitat loss, the ongoing mass mortalities of bat species due to wind turbines (Baerwald et al., 2008; Cryan \& Barclay, 2009) and white-nose syndrome (WNS) (Frick et al., 2010) highlight the urgency of understanding the physiology and ecology of bats. Since Speakman \& Thomas's (2003) comprehensive review of the physiological ecology and thermal biology of bats, knowledge of torpor expression in bats, especially in the field, has substantially expanded. More recent reviews on the topic have focused specifically on torpor use in tropical and subtropical bats (Geiser \& Stawski, 2011) or in Australian bats (Geiser, 2006).
Our aim therefore was to summarize current information on temporal heterothermy in bats worldwide in relation to reproductive status, diet and environmental factors specific to their habitats. We first reviewed the available information on torpor in bats in the context of phylogenetic groups and geography (Table 1) and discussed the evolution of heterothermy in bats. We then highlighted a number of examples illustrating fundamental connections between use of torpor by bats and other aspects of their natural history with an emphasis on reproduction and disease. These examples can inform key questions about ecology and evolution in heterothermic endotherms, but are also relevant to bat conservation. In general, the available data strongly support the importance of temporal heterothermy to the survival of individual bats and the persistence of bat populations, and we review the examples that highlight this importance.

\section{Torpor in relation to phylogeny, geography and evolution}

Traditionally, bats were grouped into two suborders: the microchiropterans and the megachiropterans. Recent molecular studies suggest an alternative grouping: (1) Yinpterochiroptera, which includes all members of the Pteropodidae (i.e. megachiropterans, old world fruit bats) and the Rhinolophidae (historically considered microchiropterans, horseshoe bats); and (2) Yangochiroptera, which includes all remaining microchiropterans (Teeling et al., 2005; Teeling, 2009).

\section{Yinpterochiroptera}

\section{Temperate}

Rhinolophid bats that inhabit temperate regions are known to hibernate (Davis, 1970). In particular, Rhinolophus ferrumequinum expresses torpor bouts of up to 2 weeks during the hibernation period (Park, Jones \& Ransome, 2000) and even longer torpor bouts have been recorded in Rhinolophus hipposideros (Harmata, 1987). Torpor has also been recorded in the South African Rhinolophus capensis (Brown \& Bernard, 1994). Australian temperate rhinolophids are known to use torpor, but there are only few data and more work is needed.

\section{Tropical/subtropical}

Pteropodids are entirely restricted to tropical/subtropical areas of the old world. The widely held view in the past was that all members of this family are strictly homeothermic (Morrison, 1959; Henshaw, 1970; Lyman, 1970; Ransome, 1990). This interpretation was supported by laboratory studies, which did not observe torpor in a number of species of medium and large pteropodids (80-1100 g) (Bartholomew, Leitner \& Nelson, 1964; McNab, 1989). Free-ranging eastern tube-nosed bats Nyctimene robinsoni also did not use torpor, but the work was conducted in a tropical area when environmental conditions were mild and food was abundant (Riek, Körtner \& Geiser, 2010). 


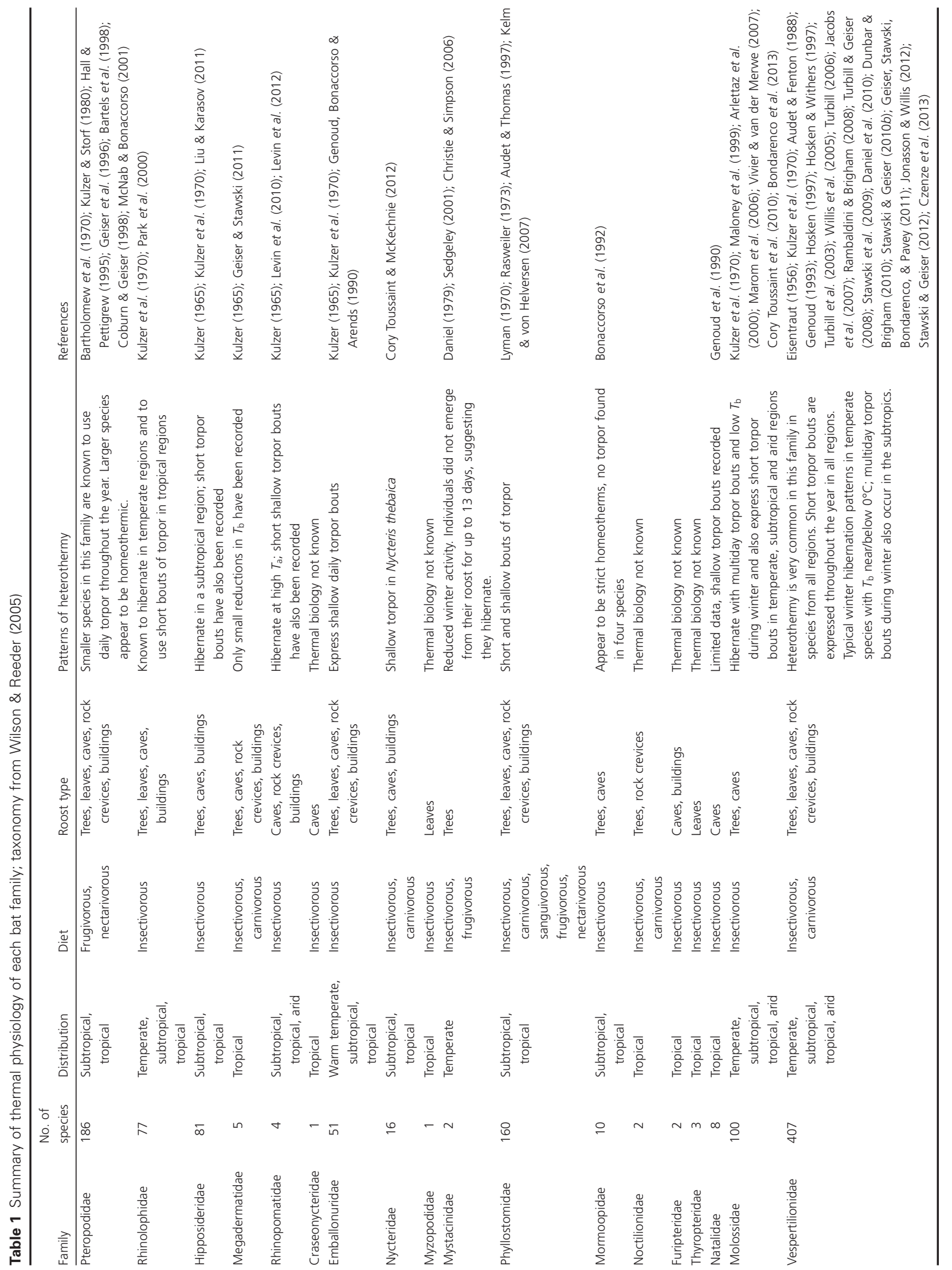


In contrast, laboratory studies have established that, especially when food is restricted, several small pteropodid species express daily torpor with $T_{\mathrm{b}}$ as low as $17.2^{\circ} \mathrm{C}$ (Bartholomew, Dawson \& Lasiewski, 1970; Kulzer \& Storf, 1980; Hall \& Pettigrew, 1995; Bartels, Law \& Geiser, 1998; Coburn \& Geiser, 1998; McNab \& Bonaccorso, 2001; Geiser, 2006). All heterothermic pteropodids were $<50 \mathrm{~g}$ and it therefore may be correct that the larger species are homeothermic (Bartholomew et al., 1964; McNab, 1989; Geiser \& Stawski, 2011). Interestingly, while torpor use is more pronounced during the cool winter period in most species, the Australian subtropical pteropodid Syconycteris australis shows an increase in torpor duration during summer, most likely due to the decreased availability of flowering plants and thus nectar (Coburn \& Geiser, 1998). This emphasizes the importance of food availability on the energy partitioning of bats and therefore its influence on the use of torpor by bats.

The rhinolophid Rhinolophus megaphyllus, from a tropical habitat in Australia, reduced its $T_{\mathrm{b}}$ to a minimum of $16^{\circ} \mathrm{C}$ under laboratory conditions, confirming that members of this family may also use torpor in a mild climate (Kulzer et al., 1970).

\section{Yangochiroptera}

\section{Temperate}

Bats from the families Vespertilionidae and Molossidae from high-latitude temperate regions are known to hibernate (Davis, 1970; Lyman, 1970; Ransome, 1990; Arlettaz et al., 2000). Hibernation by the little brown bat Myotis lucifugus, which ranges over much of North America, has received considerable attention (Hock, 1951; Matheson, Campbell \& Willis, 2010; Jonasson \& Willis, 2012; Reeder et al., 2012; Czenze, Park \& Willis, 2013). However, other species from other regions have also been examined in detail (e.g. Lausen \& Barclay, 2003; Willis, Brigham \& Geiser, 2006; Solick \& Barclay, 2007; Wojciechowski, Jefimow \& Teqgowska, 2007; Becker et al., 2013; Klug \& Barclay, 2013). Most insectivorous bats in temperate regions typically show the traditional hibernation pattern throughout winter, with multi-day torpor bouts interspersed by periodic and short arousals (Henshaw, 1970; Turbill, 2006; Hope \& Jones, 2012; Jonasson \& Willis, 2012). Although it has been claimed that some hibernating bats may express longer torpor bouts than most other hibernators (Menaker, 1964; Brack \& Twente, 1985), this has only recently been confirmed using temperature telemetry in the field with torpor bouts of up to $\sim 48$ days in M. lucifugus (Jonasson \& Willis, 2012). Despite these long torpor bouts, these small bats require fat reserves that are large relative to their body size to survive the prolonged hibernation season. Although bats have to fly, restricting the extent of fat they can store, their mass can be $30 \%$ higher at the beginning of hibernation than when they emerge in spring (Davis, 1970; Yalden \& Morris, 1975; Speakman \& Racey, 1989; Kunz, Wrazen \& Burnett, 1998; Koteja, Jurczyszyn \& Wołoszyn, 2001; Jonasson \& Willis, 2011).
In milder temperate climates, some insectivorous bats arouse throughout winter and do not immediately re-enter torpor, but forage during warm spells when insect activity presumably increases. In some of these temperate species, activity in winter appears to be routine (Ransome, 1968; Avery, 1985; Hays, Speakman \& Webb, 1992; Wojciechowski et al., 2007; Turbill \& Geiser, 2008; Hope \& Jones, 2012). Those insectivorous bats that forage during winter show less pronounced seasonal changes in body mass and consistently synchronize periodic arousals from torpor with photoperiod (Turbill \& Geiser, 2008; Hope \& Jones, 2012). On the contrary, M. lucifugus hibernating in cold climates, where insects are unavailable for many months, synchronize arousals with conspecifics with no circadian pattern to arousal (Czenze et al., 2013).

Temperate bats from both Northern and Southern Hemispheres appear to show similar patterns of torpor and thermal physiology during winter and are strongly influenced by roost microclimate (Geiser \& Brigham, 2000). However, because thermal conditions in much of the Southern Hemisphere inhabited by bats are less severe, more southern bats roost in trees for the entire year in comparison to northern bats (Turbill \& Geiser, 2008). Northern bats, especially those living at high latitudes, often require substantial refugia such as caves, which are well buffered from environmental conditions, to survive the winter. These differences in roost selection are reflected in patterns of hibernation. Tree roosts will allow hibernating bats to track weather changes and time arousals when conditions favour foraging to replenish fat stores (Dunbar \& Tomasi, 2006; Turbill, 2008; Turbill \& Geiser, 2008). Many such species are opportunistic hibernators that will remain torpid during adverse conditions and arouse to forage when conditions improve (Stawski \& Geiser, 2010a). This is favoured also by the fluctuating $T_{\mathrm{a}}$ of tree roosts, which enable passive or partially passive rewarming reducing the energetic cost of arousals (Chruszcz \& Barclay, 2002; Turbill, Körtner \& Geiser, 2008). Conversely, caves tend to be spacious, open-air environments and with little opportunity for bats to alter the microclimate via heat production, at least in winter (Jonasson \& Willis, 2012). This could help explain the energetically conservative hibernation patterns of some northern temperate vespertilionids and the strong tendency of many bat species to roost in clusters, which could trap metabolic heat locally (Davis, 1970; Kurta, 1985; Vivier \& van der Merwe, 2007; Boyles, Storm \& Brack, 2008; Jonasson \& Willis, 2012).

Many temperate bats hibernate for much of the winter, but are also known to exhibit short bouts of torpor during summer, typically after returning from foraging in the morning (Lyman, 1970; Solick \& Barclay, 2006, 2007; Turbill, 2006). In summer, these species often arouse largely passively in the middle of the day with increasing $T_{\mathrm{a}}$ and then re-enter torpor in the afternoon until the evening arousal (Turbill, Law \& Geiser, 2003; Willis \& Brigham, 2003; Turbill, 2006). Interestingly, metabolic data suggest that in hibernating bats the short torpor bouts expressed in summer are physiologically similar to the deep, prolonged torpor bouts seen during the hibernation period and differ substantially from the pattern of 
exclusively daily torpor expressed by the small pteropodids (Hock, 1951; Lyman, 1970; Geiser \& Brigham, 2000; Turbill et al., 2008; Matheson et al., 2010).

\section{Tropical/subtropical/arid}

The diversity of tropical and subtropical bat species is vast and, accordingly, variation in patterns of thermoregulation and energy balance among these species are large (Lyman, 1970). While it was previously assumed that all tropical bats are homeothermic (Henshaw, 1970), many tropical and subtropical yangochiropterans from the families Hipposideridae, Megadermatidae, Rhinopomatidae, Emballonuridae, Phyllostomidae, Natalidae, Molossidae and, especially, Vespertilionidae are in fact heterothermic (Geiser \& Stawski, 2011). While most of the data on torpor for these bats are on captive individuals, some are now available for free-ranging individuals of several species studied in the field.

In contrast to the prevailing view that subtropical species do not hibernate, multi-day torpor bouts during winter have now been recorded. Three species of subtropical insectivorous bats entered torpor bouts of 5-19 days at $T_{\mathrm{a}}$ between 4 and $25^{\circ} \mathrm{C}$ (Stawski, Turbill \& Geiser, 2009; Cory Toussaint, McKechnie \& van der Merwe, 2010; Liu \& Karasov, 2011). These data show that saving energy by employing torpor is important not only to bats in cold climates. Even in tropical areas, frequent use of short bouts of torpor in winter has now also been recorded in some free-ranging insectivorous bats and torpor bouts of longer than a day have also been observed (Geiser et al., 2011; Stawski \& Geiser, 2012).

Torpor bouts tend to be of short duration during summer in subtropical bats, such as the Angolan free-tailed bat Mops condylurus from South Africa (Vivier \& van der Merwe, 2007). Interestingly, in summer, patterns of torpor expressed by subtropical species are similar to those shown by temperate species, with one bout in the morning followed by a second in the afternoon after a period of normothermy around noon (Turbill et al., 2003).

Although temporal heterothermy appears widely spread among the tropical/subtropical yangochiropterans, some appear to be strictly homeotherms. These include four mormoopids that did not enter torpor even at low $T_{\mathrm{a}}$ and were unable to cope with $T_{\mathrm{a}}<15^{\circ} \mathrm{C}$ (Bonaccorso et al., 1992). Only a minority of tropical/subtropical bats have been investigated in terms of their thermal biology, and while current data suggest that many of these are likely heterothermic, this will not be universal.

Data on the use of torpor by bats inhabiting arid regions are also scarce. However, several studies have observed torpor use by arid zone bats, perhaps likely due to the unpredictability of rainfall and food availability in deserts (Marom et al., 2006; Daniel, Korine \& Pinshow, 2010; Levin et al., 2010; Bondarenco, Körtner \& Geiser, 2013). We predict that many desert bats are heterothermic. Torpor use was recorded throughout the year in two insectivorous bat species from the Negev Desert, Otonycteris hemprichii and Tadarida teniotis (Marom et al., 2006; Daniel et al., 2010). Hibernation at high $T_{\mathrm{a}}$ has been observed in Rhinopoma microphyllum (Levin et al., 2010). Australian arid-zone molossids, Mormopterus spp., were also found to enter torpor regularly during summer and employed largely passive arousals for rewarming from torpor (Bondarenco et al., 2013).

\section{Evolution of heterothermy in bats}

Many evolutionary studies on bats have focused on the evolution of flight, echolocation or immune function in bats (Teeling et al., 2005; Teeling, 2009; Shen et al., 2010; Zhang et al., 2013). However, the evolution of torpor in bats also has received some attention, and six candidate genes linked to hibernation were found to be positively selected for in the hibernating bat Myotis davidii, as in other hibernating species (Zhang et al., 2013). Twente \& Twente (1964) hypothesized that heterothermic bats were derived from tropical homeothermic ancestors when bats invaded cooler habitats. More recent studies propose a plesiomorphic evolution of torpor in bats. Molecular studies on the hormone leptin, important for fattening and energy balance, suggest that heterothermy was the ancestral trait in bats and that homeothermy was derived secondarily (Yuan et al., 2011). Given that many small pteropodids use torpor, and assuming that the Yinpterochiroptera are indeed a single group, a plesiomorphic origin of heterothermy in bats appears to be supported by the available data (Geiser \& Stawski, 2011). This scenario would suggest that the capacity for heterothermy has been lost in large tropical/subtropical pteropodids and in other homeothermic bats because of their size, favourable climates and an abundant food supply.

\section{Torpor in relation to the natural history of bats}

\section{Torpor and reproduction}

Mating in many bat species occurs either before they enter hibernation or during hibernation (Oxberry, 1979; Thomas, Fenton \& Barclay, 1979; Turbill, 2006; Turbill \& Geiser, 2008). Often, this leads to a mismatch in the timing of reproductive investment for male bats (i.e. late summer to early winter) versus females (i.e. spring to mid-summer), and this mismatch appears to influence the energetics of hibernation in some species. Females of hibernating species either store sperm until spring when fertilization occurs, or fertilization occurs before hibernation and implantation of embryos is delayed until females emerge in spring (Oxberry, 1979; Geiser \& Brigham, 2012). Offsetting mating from fertilization or implantation will ensure that females give birth early during spring to allow pups sufficient time to develop, grow and accumulate fat reserves for the next winter. Female little brown bats ( $M$. lucifugus) enter hibernation with larger fat reserves than males, and also use their fat reserves more slowly than males throughout winter (Jonasson \& Willis, 2011). This presumably enables females to emerge in spring with large enough fat stores for initiation and support of early pregnancy (Jonasson \& Willis, 2011). 
Table 2 Torpor depth and duration in reproductive female bats in comparison to non-reproductive bats

\begin{tabular}{|c|c|c|c|c|}
\hline & Body mass (g) & Min $T_{\mathrm{b}}$ or $T_{\text {skin }}\left({ }^{\circ} \mathrm{C}\right)$ & $\begin{array}{l}\text { Torpor bout } \\
\text { duration (days) }\end{array}$ & References \\
\hline \multicolumn{5}{|l|}{ Pregnancy } \\
\hline \multicolumn{5}{|l|}{ Pteropodidae } \\
\hline Syconycteris australis (common blossom-bat) & 18 & $\sim 22(+4.0)$ & $0.13(50 \%)^{*}$ & $\begin{array}{l}\text { Coburn \& Geiser (1998); } \\
\text { Geiser et al. (2001) }\end{array}$ \\
\hline \multicolumn{5}{|l|}{ Vespertilionidae } \\
\hline Myotis myotis (mouse-eared bat) & 25 & & $3(7.3 \%, W)$ & $\begin{array}{l}\text { Eisentraut (1937); Harmata } \\
\quad(1987)\end{array}$ \\
\hline Myotis lucifugus (little brown bat) & $6.5-10.8$ & $25.4(+4.5)^{\star}$ & $0.09(25.7 \%)^{\star}$ & Dzal \& Brigham (2013) \\
\hline Eptesicus fuscus (big brown bat) & 19 & $14.9(+13.8, W)^{*}$ & $0.15(1 \%, W)^{*}$ & $\begin{array}{c}\text { Hamilton \& Barclay (1994); } \\
\text { Grinevitch et al. (1995) }\end{array}$ \\
\hline Pipistrellus pipistrellus (pipistrelle bat) & 6 & & $\sim 15.3$ & Racey (1973) \\
\hline Lasiurus cinereus (hoary bat) & 35.8 & 5.5 & 5.6 & Willis et al. (2006) \\
\hline Corynorhinus rafinesquii (Rafinesque's big-eared bat) & $8-14$ & $33.9(+2.6)^{*}$ & $0.08(30.8 \%)^{*}$ & Johnson \& Lacki (2013) \\
\hline Nyctophilus bifax (eastern long-eared bat) & 13.8 & $25.6(+15.4)$ & $0.07(10 \%)$ & Stawski (2010) \\
\hline Otonycteris hemprichii (Hemprich's long-eared bat) & $16.5-23$ & 18 & & Daniel et al. (2010) \\
\hline Mean difference & & $+8.1 \pm 6.0$ & $20.8 \pm 18.3 \%$ & \\
\hline \multicolumn{5}{|l|}{ Lactation } \\
\hline \multicolumn{5}{|l|}{ Vespertilionidae } \\
\hline Myotis lucifugus (little brown bat) & $6.5-10.8$ & $21.2(+0.2)^{*}$ & $0.23(65.7 \%)^{*}$ & Dzal \& Brigham (2013) \\
\hline Myotis bechsteinii (Bechstein's bat) & $8.9-12.5$ & $31.8(+8.4)^{*}$ & & Dietz \& Hörig (2011) \\
\hline Myotis daubentonii (Daubenton's bat) & $7.1-10.0$ & $33.0(+10.5)^{\star}$ & & Dietz \& Hörig (2011) \\
\hline Eptesicus fuscus (big brown bat) & 19 & $25.8(+24.7, W)^{*}$ & $0.15(1 \%, W)^{*}$ & $\begin{array}{c}\text { Hamilton \& Barclay (1994); } \\
\text { Grinevitch et al. (1995) }\end{array}$ \\
\hline Lasiurus cinereus (hoary bat) & 27 & $23.6^{*}$ & & Klug \& Barclay (2013) \\
\hline Corynorhinus rafinesquii (Rafinesque's big-eared bat) & $8-14$ & $32.9(+1.6)^{*}$ & $0.23(88.5 \%)^{*}$ & Johnson \& Lacki (2013) \\
\hline Otonycteris hemprichii (Hemprich's long-eared bat) & $16.5-23$ & 29 & & Daniel et al. (2010) \\
\hline Mean difference & & $+9.1 \pm 9.8$ & $51.7 \pm 45.4 \%$ & \\
\hline
\end{tabular}

Difference between min $T_{b} / T_{\text {skin }}$ of reproductive and non-reproductive bats is shown in brackets.

Duration of torpor bouts of reproductive bats is shown in brackets as a percentage of the duration of torpor bouts of non-reproductive bats.

All values from non-reproductive bats are from the reproductive season with similar weather patterns as reproductive bats, unless obtained from winter studies and denoted with ' $W$ '.

Where possible, non-reproductive bats are females and if these values were unavailable values from males were used.

Values are the absolute min $T_{b} / T_{\text {skin }}$ or longest torpor bout duration recorded, unless denoted by '*' which indicates mean values were used.

Although torpor and reproduction were considered physiologically incompatible in the past, recent work has shown that it can be used during all reproductive stages in bats and some other heterothermic mammals (Geiser, 1996; McAllan et al., 2012; Dzal \& Brigham, 2013; Johnson \& Lacki, 2013). However, torpor is generally shallower in pregnant and lactating individuals in comparison to non-reproductive individuals, although the magnitude of this difference varies among species (Table 2). Duration of torpor bouts in pregnant and lactating bats are generally shorter than that in nonreproductive bats, but the difference in duration of torpor bouts also varies greatly among species (Table 2). The use of torpor in pregnant and lactating bats may be surprising, considering that it slows down the development of offspring (Hamilton \& Barclay, 1994; Willis et al., 2006; Stawski, 2010; Johnson \& Lacki, 2013). However, torpor in reproductive bats has several potential benefits. The most obvious of these is the potential to prevent starvation of both mother and offspring during adverse conditions, as in non-reproductive bats. An added benefit of torpor by pregnant bats could be the delay of parturition until environmental conditions can promote maximal energetic gains. Supporting this hypothesis, Willis et al. (2006) suggested that the multi-day torpor bouts they observed in pregnant hoary bats Lasiurus cinereus, a solitary, foliage roosting species, prolonged gestation until after cold weather and snow in spring, allowing the bats to give birth during warm weather and better cope with lactation, the most energetically demanding period of reproduction (Kurta et al., 1989; Wilde et al., 1995). Lactating females appear to avoid torpor use if possible, likely because low $T_{\mathrm{b}}$ slows milk production and low pup $T_{\mathrm{b}}$ will also delay their growth (Racey \& Speakman, 1987; Audet \& Fenton, 1988; Chruszcz \& Barclay, 2002; Lausen \& Barclay, 2003; Daniel et al., 2010; Pretzlaff, Kerth \& Dausmann, 2010). Lactating bats may also be better able to avoid torpor than pregnant individuals because after parturition, wing loading is dramatically reduced, which likely improves foraging efficiency and the potential to acquire energy (Chruszcz \& Barclay, 2002). However, shallow torpor has even been recorded in lactating female bats to possibly save energy in between feeding bouts (Johnson \& Lacki, 
2013). Reproductive male bats and non-reproductive female bats are often considered as similar in terms of the trade-offs between costs and benefits of heterothermy (Grinevitch, Holroyd \& Barclay, 1995; Stawski, 2010). However, depth of torpor bouts in male Myotis spp. decreased from early to advanced spermatogenesis (i.e. from spring to autumn), and this change was independent of seasonal change in $T_{\mathrm{a}}$ (Dietz \& Hörig, 2011). This suggests that avoidance of torpor at certain times of the annual cycle is also important for reproductive success in males.

In some species, physiological constraints appear to prevent bats from expressing extensive torpor during the reproductive period. For example, in $S$. australis measured in the laboratory, depth of torpor in pregnant females was similar to that of non-reproductive females in the same study, but the duration of torpor was shorter in the former (Geiser, Körtner \& Law, 2001), suggesting that there was a physiological change. On the contrary, other bat species appear to use roost selection to promote or avoid torpor use during reproductive periods rather than or in addition to physiological differences. In the wild, reproductive females often roost in clusters (Dwyer \& Harris, 1972) and this may enable them to minimize or even avoid torpor use while still saving energy by increasing roost $T_{\mathrm{a}}$ (Hamilton \& Barclay, 1994; Cryan \& Wolf, 2003; Willis \& Brigham, 2007; Pretzlaff et al., 2010). Males, on the contrary, may roost solitarily to promote torpor (Hamilton \& Barclay, 1994; Cryan \& Wolf, 2003). Laboratory work conducted under the same environmental conditions suggests that torpor patterns are similar between sexes and reproductive states (Turbill \& Geiser, 2006), further supporting the view that different roosting preferences are, to a large extent, responsible for the differences in torpor patterns among gender and reproductive states in bats.

\section{Costs and benefits of torpor}

While torpor results in large energy savings, it entails several possible disadvantages. These include reduced mobility, compromised immunocompetence, accumulation of metabolic wastes and memory loss (Millesi et al., 2001; Prendergast et al., 2002; Humphries, Thomas \& Kramer, 2003). One obvious cost of torpor is the dramatically reduced function of skeletal muscle, which can render torpid bats more susceptible to predation. Although this is true at very low $T_{\mathrm{b}}$, recent data suggest that torpid animals, including bats, are more mobile than is widely assumed, with torpid bats capable of flight at $T_{\mathrm{b}}$ as low as $20^{\circ} \mathrm{C}$ (Bradley \& O'Farrell, 1969; Willis \& Brigham, 2003; Rojas, Körtner \& Geiser, 2012). Another disadvantage of torpor is reduced immunocompetence during deep torpor (Prendergast et al., 2002), which apparently is possible because growth of bacteria is reduced at low $T_{\mathrm{b}}$ (Bouma, Carey \& Kroese, 2010). Moreover, brain function appears to be compromised following arousal from torpor, and while the long-term costs are currently uncertain, experimental evidence suggests that memory may be impaired (Millesi et al., 2001; Thompson, Montiglio \& Humphries, 2013). Such costs appear to be the reason why some species use torpor only as a last resort when energy demands cannot be met because of low food availability (Grinevitch et al., 1995; Humphries et al., 2003; Boyles et al., 2007).

In contrast to bat species that use torpor only during emergency situations, other bats use it regularly without the apparent need to save energy (Stawski \& Geiser, 2010b; Geiser \& Brigham, 2012). Like any trait, this variation appears to be driven by differences among species in how the balance of costs and benefits of torpor influence reproductive fitness (Angilletta et al., 2010). For example, torpor during summer by subtropical insectivorous bats, a time when $T_{\mathrm{a}}$ is mild and insects are abundant, suggests that torpor has functions beyond energy conservation and that negative effects of torpor for these species are minimal (Bronner, Maloney \& Buffenstein, 1999; Turbill et al., 2003; Vivier \& van der Merwe, 2007; Stawski \& Geiser, 2010b). Subtropical Nyctophilus bifax in better body condition during summer used torpor more frequently than those in poorer condition (Stawski \& Geiser, 2010b). Similarly, temperate $R$. ferrumequinum foraged during winter only when body condition was poor; fat bats remained in hibernation (Park et al., 2000). This suggests that an additional benefit of torpor, in addition to energy and water savings, could be its potential to reduce exposure to predators by allowing animals to remain inactive in a sheltered roost or hibernaculum (Geiser \& Brigham, 2012; Bieber et al., 2013). Although bats are longerlived than other mammals of similar size, partially attributed to flight, hibernating bats live much longer on average than homeothermic bats, supporting the argument that torpor may reduce mortality from predation and also likely from starvation (Wilkinson \& South, 2002; Brunet-Rossinni \& Austad, 2004; Munshi-South \& Wilkinson, 2010; Turbill, Bieber \& Ruf, 2011). Thus, the reduced energy and foraging requirements resulting from torpor may contribute to extending longevity in heterothermic bats (Brunet-Rossinni \& Austad, 2004; Munshi-South \& Wilkinson, 2010).

\section{Torpor, parasites and pathogens}

Parasites are likely a selective force for many bats, especially social species that aggregate in large numbers. In temperate regions, ectoparasites appear to be more prevalent on juveniles and adult female vespertilionid bats in comparison to adult males (Lučan, 2006; Christe et al., 2007; Czenze \& Broders, 2011). This could be attributed to the roosting preferences of bats, where reproductive females often roost in clusters and at higher $T_{\mathrm{a}}$, whereas males and non-reproductive females often roost solitarily and at lower $T_{\mathrm{a}}$ (Hamilton \& Barclay, 1994). The roosting preferences of reproductive females could enhance ectoparasite transmission and survival, and ectoparasite infestation rates are higher during the lactation and post-lactation periods and are lower during movement periods (Lučan, 2006; Christe et al., 2007; Czenze \& Broders, 2011). Bats with high ectoparasite loads generally have poor body condition (Lučan, 2006), which could affect torpor use either by increasing the use of torpor to conserve energy or by decreasing the use of torpor to increase available foraging times to replenish energy stores. Torpor does appear 
to reduce the numbers of some ectoparasites, but this appears to be more prevalent in cold-temperate regions, whereas ectoparasite numbers do not change significantly with season in warm tropical regions (Geiser \& Brigham, 2012).

Bats are increasingly being studied from a wildlife disease perspective in part because of their role in a number of highprofile zoonotic disease outbreaks (Turmelle \& Olival, 2009; Schinnerl et al., 2011; Wang et al., 2011; Hayman et al., 2013; Luis et al., 2013). The highly social colonial roosting pattern of some bats with high rates of physical contact among individuals, and the dependence on roosts hosting multiple species (e.g. caves and mines), has presumably driven the evolution of a particularly diverse range of pathogens (Luis et al., 2013). Given close links between roosting behaviour, sociality and thermoregulation, knowledge on the use of torpor in bats may have a role to play in our understanding of bat disease and their zoonotic potential. For example, recently, Luis et al. (2013) showed that the tendency to express torpor reduces the likelihood that bat and rodent species will host zoonotic viruses, which suggests that torpor may influence pathogen diversity in bats. Additionally, the rate of virus replication may be decreased during torpor bouts as a result of the reduction in $T_{\mathrm{b}}$ and MR (Wang et al., 2011), which suggests that, in addition to possibly reducing the risk of predation, use of torpor could also reduce the risk of pathogen exposure. Links between coloniality, thermoregulation and disease in bats are clearly an important area for future study for both wildlife disease ecology and human public health.

\section{White-nose syndrome}

In terms of disease, the ability to express long-term torpor is likely beneficial when it comes to evading pathogens because growth of most typical mammalian pathogens (i.e. bacteria and viruses) depends on relatively high $T_{\mathrm{b}}$ (Bouma et al., 2010). This could explain why some bat species (and other hibernators) can afford to significantly down-regulate the immune response during winter (Moore et al., 2013). However, this strategy appears to be failing for many North American bat species. Bat populations in eastern North America are being severely affected by WNS, which is caused by the cold-tolerant fungal pathogen Geomyces destructans (Blehert et al., 2009; Warnecke et al., 2012; Lorch et al., 2013). Mortality from WNS was first confirmed during the winter of $2007 / 2008$ and the disease has now spread rapidly throughout the eastern United States and Canada (Blehert et al., 2009). The fungus also occurs on bats in Europe, where it does not cause mass mortality, and experimental evidence suggests that G. destructans is a novel, invasive pathogen to North America (Warnecke et al., 2012). The fungus invades the epidermis of infected bats and causes other clinical signs such as electrolyte depletion and emaciation and ultimately death for many individuals (Reichard \& Kunz, 2009; Cryan et al., 2013; Lorch et al., 2013; Warnecke et al., 2013).

Although the exact mechanism underlying mortality is uncertain, infected bats arouse up to three times more often than healthy bats during hibernation and are unable to survive the hibernation season due to premature depletion of fat reserves (Reeder et al., 2012; Warnecke et al., 2012). Infected bats exhibit clinical signs of hypotonic dehydration with reduced plasma electrolyte levels $\left(\mathrm{Na}^{+}\right.$and $\left.\mathrm{Cl}^{-}\right)$potentially resulting from fluid loss across fungal lesions in the highly vascularized skin of the wings (Cryan et al., 2013; Warnecke et al., 2013). One explanation for increased arousal frequency, consistent with fluid loss and electrolyte depletion, has been called the dehydration hypothesis (Cryan et al., 2010) and is related to the fact that rates of evaporative water loss and duration of torpor bouts are correlated in hibernators (Thomas \& Geiser, 1997). Thus, wing lesions caused by the fungus could lead to increased water loss, which could be the trigger for an increase in arousal frequency and premature fat depletion (Cryan et al., 2010, 2013; Warnecke et al., 2013). WNS affects different bat species disproportionately, with some exhibiting very little response, while in others, mortality rates are very high. Differences in water loss among species are one factor that could influence this variation. Little brown bats (M. lucifugus), for example, are particularly affected by WNS and have higher rates of evaporative water loss in comparison to other species, such as European Natterer's bats Myotis nattereri, which may be susceptible to G. destructans but do not die from WNS (Willis et al., 2011). For some species, hibernacula with the highest humidity appear to have the highest mortality rates (Langwig et al., 2012). One hypothesis to explain this observation is that species and individuals with high intrinsic rates of water loss select the highest humidity environments for hibernation but that these humid environments also favour rapid growth of the fungus. This would explain why these bats, which normally benefit from high humidity environments during hibernation, suffer such high mortality from WNS.

A disease that specifically targets torpid mammalian hibernators is unprecedented and the rapid emergence of WNS has highlighted the importance of more data on basic aspects of hibernation in bats. More information is needed on physiological triggers for arousal, immune function during hibernation, behaviours like clustering and microhabitat selection, anatomy and physiology of wing tissue and links between hibernation physiology, life-history traits and ecology. It is also crucial to determine whether mitigation or management strategies are feasible and to help develop those strategies to deal with WNS.

\section{Conclusions and directions for future research}

Many bats are small and have high energetic demands for both activity and maintenance processes. Therefore, torpor has likely been a key survival strategy for the group throughout their evolutionary history (Geiser \& Stawski, 2011). By being flexible in their use of torpor, bats can adjust their $T_{\mathrm{b}}$ and MR depending on foraging success and the size of their energy stores (Stawski \& Geiser, 2011). While bats with strict hibernation requirements may be negatively affected by climate change and pathogens (Humphries, Thomas \& Speakman, 2002; Bouma et al., 2010), those species that are flexible in their use of torpor will likely have an increased 
chance of survival (Stawski \& Geiser, 2012). Recent evidence suggests that temporal heterothermy is an important longterm survival mechanism and that the majority of mammals that have recently gone extinct were likely unable to use torpor (Geiser \& Turbill, 2009; Geiser \& Stawski, 2011; Turbill et al., 2011). Data obtained on thermal physiology, reproductive ecology and roosting requirements of bats, in regard to optimal roost temperatures and feeding locations, can be used to develop effective conservation and management plans (Brack, 2007; Encarnação, Otto \& Becker, 2012). The crisis for bat conservation resulting from WNS illustrates the importance of more data on the basics of thermal physiology and hibernation ecology of bats to potentially enable informed and effective management responses. The use of torpor is fundamentally linked with many aspects of the ecology and natural history of bats and improved understanding of temporal heterothermy in this diverse group will enhance our understanding of bat ecology and conservation in general.

\section{Acknowledgements}

This review was supported by funding from Jagiellonian University, the European Union under the European Social Fund and the University of New England Deputy Vice-Chancellor (Research) to C.S.; from the Natural Sciences and Engineering Research Council (Canada) Discovery Grant and University of Winnipeg Chancellor's Research Chair to C.K.R.W.; and from the Australian Research Council to F.G.

\section{References}

Angilletta, M.J., Jr., Cooper, B.S., Schuler, M.S. \& Boyles, J.G. (2010). The evolution of thermal physiology in endotherms. Front. Biosci. 2, 861-881.

Arlettaz, R., Ruchet, C., Aeschimann, J., Brun, E., Genoud, M. \& Vogel, P. (2000). Physiological traits affecting the distribution and wintering strategy of the bat Tadarida teniotis. Ecology 81, 1004-1014.

Audet, D. \& Fenton, M.B. (1988). Heterothermy and the use of torpor by the bat Eptesicus fuscus (Chiroptera:

Vespertilionidae): a field study. Physiol. Zool. 61, 197-204.

Audet, D. \& Thomas, D.W. (1997). Facultative hypothermia as a thermoregulatory strategy in the phyllostomid bats, Carollia perspicillata and Sturnira lilium. J. Comp. Physiol. B 16, 146-152.

Avery, M.I. (1985). Winter activity of pipistrelle bats. $J$. Anim. Ecol. 54, 721-738.

Baerwald, E.F., D’Amours, G.H., Klug, B.J. \& Barclay, R.M.R. (2008). Barotrauma is a significant cause of bat fatalities at wind turbines. Curr. Biol. 18, R695-R696.

Bartels, W., Law, B.S. \& Geiser, F. (1998). Daily torpor and energetics in a tropical mammal, the northern blossom-bat Macroglossus minimus (Megachiroptera). J. Comp. Physiol. B 168, 233-239.
Bartholomew, G.A., Leitner, P. \& Nelson, J.E. (1964). Body temperature, oxygen consumption, and heart rate in three species of Australian flying foxes. Physiol. Zool. 37, 179198.

Bartholomew, G.A., Dawson, W.R. \& Lasiewski, R.C. (1970). Thermoregulation and heterothermy in some of the smaller flying foxes (Megachiroptera). Z. Vergl. Physiol. 70, 196209.

Becker, N.I., Tschapka, M., Kalko, E.K.V. \& Encarnação, J.A. (2013). Balancing the energy budget in free-ranging male Myotis daubentonii bats. Physiol. Biochem. Zool. 86, 361-369.

Ben-Hamo, M., Muñoz-Garcia, A., Williams, J.B., Korine, C. \& Pinshow, B. (2013). Waking to drink: rates of evaporative water loss determine arousal frequency in hibernating bats. J. Exp. Biol. 216, 573-577.

Bieber, C., Lebl, K., Stalder, G., Geiser, F. \& Ruf, T. (2013). Body mass-dependent use of hibernation by dormice: why not prolong the active season, if they can? Funct. Ecol. 292, 86-100. (Online DOI: 10.1111/1365-2435.12173).

Blehert, D.S., Hicks, A.C., Behr, M., Métier, C.U., Berlowski-Zier, B.M., Buckles, E.L., Coleman, J.T.H., Darling, S.R., Gorgas, A., Niver, R., Okoniewski, J.C., Rudd, R.J. \& Stone, W.B. (2009). Bat white-nose syndrome: an emerging fungal pathogen? Science 323, 227.

Bonaccorso, F.J., Amends, A., Genoud, M., Canton, D. \& Morton, T. (1992). Thermal ecology of moustached and ghost-faced bats (Mormoopidae) in Venezuela. J. Mammal. 73, 365-378.

Bondarenco, A., Körtner, G. \& Geiser, F. (2013). Some like it cold: summer torpor by freetail bats in the Australian arid zone. J. Comp. Physiol. B 183, 1113-1122.

Bouma, H.R., Carey, H.V. \& Kroese, F.G. (2010). Hibernation: the immune system at rest? J. Leukoc. Biol. 88, 619624.

Boyles, J.G., Dunbar, M.B., Storm, J.J. \& Brack, V., Jr. (2007). Energy availability influences microclimate selection of hibernating bats. J. Exp. Biol. 210, 4345-4350.

Boyles, J.G., Storm, J.J. \& Brack, V., Jr. (2008). Thermal benefits of clustering during hibernation: a field test of competing hypotheses on Myotis sodalis. Funct. Ecol. 22, 632-636.

Brack, V., Jr. (2007). Temperatures and locations used by hibernating bats, including Myotis sodalis (Indiana bat), in a limestone mine: implications for conservation and management. Environ. Manage. 40, 739-746.

Brack, V., Jr. \& Twente, J.W. (1985). The duration of the period of hibernation of three species of vespertilionid bats. 1. Field studies. Can. J. Zool. 63, 2952-2954.

Bradley, W.G. \& O'Farrell, M.J. (1969). Temperature relationships in the Western Pipistrelle (Pipistrellus hesperus). In Physiological systems in semiarid environments: 85-96. Hoff, C.C. \& Riedesel, M.L. (Eds). Albuquerque: University of New Mexico Press. 
Bronner, G.N., Maloney, S.K. \& Buffenstein, R. (1999). Survival tactics within thermally-challenging roosts: heat tolerance and cold sensitivity in the Angolan free-tailed bat, Mops condylurus. S. Afr. J. Zool. 34, 1-10.

Brown, D.R. \& Bernard, R.T.F. (1994). Thermal preference of Schreiber's long-fingered (Miniopterus schreibersii) and Cape horseshoe (Rhinolophus capensis) bats. Comp. Biochem. Physiol. A 107, 439-449.

Brunet-Rossinni, A.K. \& Austad, S.N. (2004). Ageing studies on bats: a review. Biogerontology 5, 211-222.

Christe, P., Glaizot, O., Evanno, G., Bruyndonckx, N., Devevey, G., Yannic, G., Patthey, P., Maeder, A., Vogel, P. \& Arlettaz, R. (2007). Host sex and ectoparasites choice: preference for, and higher survival on female hosts. $J$. Anim. Ecol. 76, 703-710.

Christie, J.E. \& Simpson, W. (2006). Influence of winter weather conditions on lesser short-tailed bat (Mystacina tuberculata) activity in Nothofagus forest, Fiordland. N. Z J. Zool. 33, 133-140.

Chruszcz, B.J. \& Barclay, R.M.R. (2002). Thermoregulatory ecology of a solitary bat, Myotis evotis, roosting in rock crevices. Funct. Ecol. 16, 18-26.

Coburn, D.K. \& Geiser, F. (1998). Seasonal changes in energetics and torpor patterns in the subtropical blossom-bat Syconycteris australis (Megachiroptera). Oecologia 113, 467-473.

Cory Toussaint, D. \& McKechnie, A.E. (2012). Interspecific variation in thermoregulation among three sympatric bats inhabiting a hot, semi-arid environment. J. Comp. Physiol. B 182, 1129-1140.

Cory Toussaint, D., McKechnie, A.E. \& van der Merwe, M. (2010). Heterothermy in free-ranging male Egyptian freetailed bats (Tadarida aegyptiaca) in a subtropical climate. Mamm. Biol. 75, 466-470.

Cryan, P.M. \& Barclay, R.M.R. (2009). Causes of bat fatalities at wind turbines: hypotheses and predictions. $J$. Mammal. 90, 1330-1340.

Cryan, P.M., Meteyer, C.U., Boyles, J.G. \& Blehert, D.S. (2010). Wing pathology of white-nose syndrome in bats suggests life-threatening disruption of physiology. $B M C$ Biol. 8, 135-142.

Cryan, P.M., Meteyer, C.U., Blehert, D.S., Lorch, J.M., Reeder, D.M., Turner, G.G., Webb, J., Behr, M., Verant, M., Russell, R.E. \& Castle, K.T. (2013). Electrolyte depletion in white-nose syndrome bats. J. Wildl. Dis. 49, 398 402.

Cryan, P.M. \& Wolf, B.O. (2003). Sex differences in the thermoregulation and evaporative water loss of a heterothermic bat, Lasiurus cinereus, during its spring migration. J. Exp. Biol. 206, 3381-3390.

Czenze, Z.J. \& Broders, H.G. (2011). Ectoparasite community structure of two bats (Myotis lucifugus and M. septentrionalis) from the Maritimes of Canada. J. Parasitol. Res. 2011, 341535.
Czenze, Z.J., Park, A.D. \& Willis, C.K.R. (2013). Staying cold through dinner: cold-climate bats rewarm during hibernation. J. Comp. Physiol. B 183, 859-866.

Daniel, M.J. (1979). The New Zealand short-tailed bat, Mystacina tuberculata: a review of present knowledge. $N$. Z. J. Zool. 6, 357-370.

Daniel, S., Korine, C. \& Pinshow, B. (2010). The use of torpor in reproductive female Hemprich's long-eared bats (Otonycteris hemprichii). Physiol. Biochem. Zool. 83, 142148.

Davis, W.H. (1970). Hibernation: ecology and physiological ecology. In Biology of bats: 265-300. Wimsatt, W.A. (Ed.). New York and London: Academic Press.

Dietz, M. \& Hörig, A. (2011). Thermoregulation of treedwelling temperate bats - a behavioural adaptation to force live history strategry. Folia Zool. 60, 5-16.

Dunbar, M.B. \& Brigham, R.M. (2010). Thermoregulatory variation among populations of bats along a latitudinal gradient. J. Comp. Physiol. B 180, 885-893.

Dunbar, M.B. \& Tomasi, T.E. (2006). Arousal patterns, metabolic rate, and an energy budget of eastern red bats (Lasiurus borealis) in winter. J. Mammal. 87, 1096-1102.

Dwyer, P.D. \& Harris, J.A. (1972). Behavioral acclimatization to temperature by pregnant Miniopterus (Chiroptera). Physiol. Zool. 45, 14-21.

Dzal, Y.A. \& Brigham, R.M. (2013). The tradeoff between torpor use and reproduction in little brown bats (Myotis lucifugus). J. Comp. Physiol. B 183, 279-288.

Eisentraut, M. (1937). Die Wirkung niedriger Temperatur auf die Embryonalentwicklung bei Fledermäusen. Biol. Zbl. 57, 59-74.

Eisentraut, M. (1956). Der Winterschlaf mit seinen ökologischen und physiologischen Begleiterscheinungen. Jena: G. Fischer.

Encarnação, J.A., Otto, M.S. \& Becker, N.I. (2012). Thermoregulation in male temperate bats depends on habitat characteristics. J. Therm. Biol. 37, 564-569.

Fenton, M.B. (1983). Just bats: Toronto: University of Toronto Press.

Frick, W.F., Pollock, J.F., Hicks, A.C., Langwig, K.E., Reynolds, D.S., Turner, G.G., Butchkoki, C.M. \& Kunz, T.H. (2010). An emerging disease causes regional population collapse of a common North American bat species. Science 329, 679-682.

Geiser, F. (1996). Torpor in reproductive endotherms. In Adaptations to the cold: tenth international hibernation symposium: 81-86. Geiser, F., Hulbert, A.J. \& Nicol, S.C. (Eds). Armidale: University of New England Press.

Geiser, F. (2006). Energetics, thermal biology, and torpor in Australian bats. In Functional and evolutionary ecology of bats: 5-22. Zubaid, A., McCracken, G.F. \& Kunz, T.H. (Eds). New York: Oxford University Press.

Geiser, F. (2013). Hibernation. Curr. Biol. 23, R188-R193. 
Geiser, F. \& Brigham, R.M. (2000). Torpor, thermal biology, and energetics in Australian long-eared bats (Nyctophilus). J. Comp. Physiol. B 170, 153-162.

Geiser, F. \& Brigham, R.M. (2012). The other functions of torpor. In Living in a seasonal world: thermoregulatory and metabolic adaptations: 109-121. Ruf, T., Bieber, C., Arnold, W. \& Millesi, E. (Eds). Heidelberg: Springer.

Geiser, F. \& Ruf, T. (1995). Hibernation versus daily torpor in mammals and birds: physiological variables and classification of torpor patterns. Physiol. Zool. 68, 935-966.

Geiser, F. \& Stawski, C. (2011). Hibernation and torpor in tropical and subtropical bats in relation to energetics, extinctions, and the evolution of endothermy. Integra. Comp. Biol. 51, 337-348.

Geiser, F. \& Turbill, C. (2009). Hibernation and daily torpor minimize mammalian extinctions. Naturwissenschaften 96, 1235-1240.

Geiser, F., Coburn, D.K., Körtner, G. \& Law, B.S. (1996). Thermoregulation, energy metabolism, and torpor in blossom-bats, Syconycteris australis (Megachiroptera). J. Zool. (Lond.) 239, 583-590.

Geiser, F., Körtner, G. \& Law, B.S. (2001). Daily torpor in a pregnant common blossom-bat (Syconycteris australis: Megachiroptera). Aust. Mammal. 23, 53-56.

Geiser, F., Stawski, C., Bondarenco, A. \& Pavey, C.R. (2011). Torpor and activity in a free-ranging tropical bat: implications for the distribution and conservation of mammals? Naturwissenschaften 98, 447-452.

Genoud, M. (1993). Temperature regulation in subtropical tree bats. Comp. Biochem. Physiol. A 104, 321-331.

Genoud, M., Bonaccorso, F.J. \& Arends, A. (1990). Rate of metabolism and temperature regulation in two small tropical insectivorous bats (Peropteryx macrotis and Natalus tumidirostris). Comp. Biochem. Physiol. A 97, 229-234.

Grinevitch, L., Holroyd, S.L. \& Barclay, R.M.R. (1995). Sex differences in the use of daily torpor and foraging time by big brown bats (Eptesicus fuscus) during the reproductive season. J. Zool. (Lond.) 235, 301-309.

Hall, L.S. \& Pettigrew, J. (1995). The bat with the stereo nose. Aust. Nat. Hist. 24, 26-28.

Hamilton, I.M. \& Barclay, R.M.R. (1994). Patterns of daily torpor and day-roost selection by male and female big brown bats (Eptesicus fuscus). Can. J. Zool. 72, 744-749.

Harmata, W. (1987). The frequency of winter sleep interruptions in two species of bats hibernating in limestone tunnels. Acta Theriol. 32, 331-332.

Hayman, D.T.S., Bowen, R.A., Cryan, P.M., McCracken, G.F., O’Shea, T.J., Peel, A.J., Gilbert, A., Webb, C.T. \& Wood, J.L.N. (2013). Ecology of zoonotic infectious diseases in bats: current knowledge and future directions. Zoonoses Public Health 60, 2-21.

Hays, G.C., Speakman, J.R. \& Webb, P.I. (1992). Why do brown long-eared bats (Plecotus auritus) fly in winter? Physiol. Zool. 65, 554-567.
Henshaw, R.E. (1970). Thermoregulation in bats. In About bats: 188-232. Slaughter, B.H. \& Walton, D.W. (Eds). Dallas: Southern Methodist University Press.

Hock, R.J. (1951). The metabolic rates and body temperatures of bats. Biol. Bull. 101, 289-299.

Hope, P.R. \& Jones, G. (2012). Warming up for dinner: torpor and arousal in hibernating Natterer's bats (Myotis nattereri) studied by radio telemetry. J. Comp. Physiol. B 182, 569-578.

Hosken, D.J. (1997). Thermal biology and metabolism of the greater long-eared bat, Nyctophilus major (Chiroptera: Vespertilionidae). Aust. J. Zool. 45, 145-156.

Hosken, D.J. \& Withers, P.C. (1997). Temperature regulation and metabolism of an Australian bat, Chalinolobus gouldii (Chiroptera: Vespertilionidae) when euthermic and torpid. J. Comp. Physiol. B 167, 71-80.

Humphries, M.M., Thomas, D.W. \& Speakman, J.R. (2002). Climate-mediated energetic constraints on the distribution of hibernating mammals. Nature 418, 313-316.

Humphries, M.M., Thomas, D.W. \& Kramer, D.L. (2003). The role of energy availability in mammalian hibernation: a cost-benefit approach. Physiol. Biochem. Zool. 76, 165-179.

Jacobs, D.S., Kelly, E.J. \& Stoffberg, S. (2007). Thermoregulation in two free-ranging subtropical insectivorous bat species: Scotophilus species (Vespertilionidae). Can. J. Zool. 85, 883-890.

Johnson, J.S. \& Lacki, M.J. (2013). Summer heterothermy in Rafinesque's big-eared bats (Corynorhinus rafinesquii) roosting in tree cavities in bottomland hardwood forests. $J$. Comp. Physiol. B 183, 709-721.

Jonasson, K.A. \& Willis, C.K.R. (2011). Changes in body condition of hibernating bats support the thrifty female hypothesis and predict consequences for populations with white-nose syndrome. PLoS ONE 6, e21061.

Jonasson, K.A. \& Willis, C.K.R. (2012). Hibernation energetics of free-ranging little brown bats. J. Exp. Biol. 215, 2141-2149.

Kelm, D.H. \& von Helversen, O. (2007). How to budget metabolic energy: torpor in a small neotropical mammal. $J$. Comp. Physiol. B 177, 667-677.

Klug, B.J. \& Barclay, R.M.R. (2013). Thermoregulation during reproduction in the solitary, foliage-roosting hoary bat (Lasiurus cinereus). J. Mammal. 94, 477-487.

Koteja, P., Jurczyszyn, M. \& Wołoszyn, B.W. (2001). Energy balance of hibernating mouse-eared bat Myotis myotis: a study with a TOBEC instrument. Acta Theriol. 46, 1-12.

Kulzer, E. (1965). Temperaturregulation bei Fledermäusen (Chiroptera) aus verschiedenen Klimazonen. Z. Vergl. Physiol. 50, 1-34.

Kulzer, E. \& Storf, R. (1980). Schlaf-lethargie bei dem afrikanischen Langzungenflughund Megaloglossus woermanni Pagenstecher, 1885. Z. Säugetierkd. 45, 23-29.

Kulzer, E., Nelson, J.E., McKean, J.L. \& Möhres, P.F. (1970). Untersuchungen über die Temperaturregulation australischer Fledermäuse. Z. Vergl. Physiol. 69, 426-451. 
Kunz, T.H., Wrazen, J.A. \& Burnett, C.D. (1998). Changes in body mass and fat reserves in pre-hibernating little brown bats (Myotis lucifugus). Ecoscience 5, 8-17.

Kunz, T.H., de Torrez, E.B., Bauer, D., Lobova, T. \& Fleming, T.H. (2011). Ecosystem services provided by bats. Ann. N. Y. Acad. Sci. 1223, 1-38.

Kurta, A. (1985). External insulation available to a nonnesting mammal, the little brown bat (Myotis lucifugus). Comp. Biochem. Physiol. A 82, 413-420.

Kurta, A., Bell, G.P., Nagy, K.A. \& Kunz, T.H. (1989). Energetics of pregnancy and lactation in free-ranging little brown bats (Myotis lucifugus). Physiol. Zool. 62, 804-818.

Langwig, K.E., Frick, W.F., Bried, J.T., Hicks, A.C., Kunz, T.H. \& Marm Kilpatrick, A. (2012). Sociality, densitydependence and microclimates determine the persistence of populations suffering from a novel fungal disease, whitenose syndrome. Ecol. Lett. 15, 1050-1057.

Lausen, C.L. \& Barclay, R.M.R. (2003). Thermoregulation and roost selection by reproductive female big brown bats (Eptesicus fuscus) roosting in rock crevices. J. Zool. (Lond.) 260, 235-244.

Levin, E., Ar, A., Hefetz, A., Yom-Tov, Y. \& Kronfeld-Schor, N. (2010). Some like it hot: hibernation patterns of the greater mouse-tailed bat (Rhinopoma microphyllum). Australian and New Zealand Society for Comparative Physiology and Biochemistry. Conference Handbook 27, 26.

Levin, E., Ar, A., Yom-Tov, Y. \& Kronfeld-Schor, N. (2012). Summer torpor and sexual segregation in the subtropical bat Rhinopoma microphyllum. In Living in a seasonal world: thermoregulatory and metabolic adaptations: 167-174. Ruf, T., Bieber, C., Arnold, W. \& Millesi, E. (Eds). Heidelberg: Springer.

Liu, J.-N. \& Karasov, W.H. (2011). Hibernation in warm hibernacula by free-ranging Formosan leaf-nosed bats, Hipposideros terasensis, in subtropical Taiwan. J. Comp. Physiol. B 181, 125-135.

Lorch, J.M., Muller, L.K., Russell, R.E., O’Connor, M., Lindner, D.L. \& Blehert, D.S. (2013). Distribution and environmental persistence of the causative agent of whitenose syndrome, Geomyces destructans, in bat hibernacula of the eastern United States. Appl. Environ. Microbiol. 79, 1293-1301.

Lučan, R.K. (2006). Relationships between the parasitic mite Spinturnix andegavinus (Acari: Spinturnicidae) and its bat host, Myotis daubentonii (Chiroptera: Vespertilionidae): seasonal, sex- and age-related variation in infestation and possible impact of the parasite on the host condition and roosting behaviour. Folia Parasit. 53, 147-152.

Luis, A.D., Hayman, D.T., O’Shea, T.J., Cryan, P.M., Gilbert, A.T., Pulliam, J.R., Mills, J.N., Timonin, M.E., Willis, C.K.R., Cunningham, A.A., Fooks, A.R., Rupprecht, C.E., Wood, J.L.N. \& Webb, C.T. (2013). A comparison of bats and rodents as reservoirs of zoonotic viruses: are bats special? Proc. Roy. Soc. Lond. Ser. B $\mathbf{2 8 0}$, 1756-1765.

Lyman, C.P. (1970). Thermoregulation and metabolism in bats. Hibernation: ecology and physiological ecology. In Biology of bats: 301-330. Wimsatt, W.A. (Ed.). New York and London: Academic Press.

Maloney, S.K., Bronner, G.N. \& Buffenstein, R. (1999). Thermoregulation in the Angolan free-tailed bat Mops condylurus: a small mammal that uses hot roosts. Physiol. Biochem. Zool. 72, 385-396.

Marom, S., Korine, C., Wojciechowski, M.S., Tracy, C.R. \& Pinshow, B. (2006). Energy metabolism and evaporative water loss in the European free-tailed bat and Hemprich's long-eared bat (Microchiroptera): species sympatric in the Negev Desert. Physiol. Biochem. Zool. 79, 944-956.

Martin, T.G., Nelly, S., Burbidge, A.A., Arnall, S., Garnett, S.T., Hayward, M.W., Lumsden, L.F., Menkhorst, P., McDonald-Madden, E. \& Possingham, H.P. (2012). Acting fast helps avoid extinction. Conserv. Lett. 5, 274 280.

Matheson, A.L., Campbell, K.L. \& Willis, C.K.R. (2010). Feasting, fasting and freezing: energetic effects of meal size and temperature on torpor expression by little brown bats Myotis lucifugus. J. Exp. Biol. 213, 2165-2173.

McAllan, B.M., Feay, N., Bradley, A.J. \& Geiser, F. (2012). The influence of reproductive hormones on the torpor patterns of the marsupial Sminthopsis macroura: bet-hedging in an unpredictable environment. Gen. Comp. Endocrinol. 179, 265-276.

McGuire, L.P. \& Boyle, W.A. (2013). Altitudinal migration in bats: evidence, patterns, and drivers. Biol. Rev. 88, 767-786.

McNab, B.K. (1982). Evolutionary alternatives in the physiological ecology of bats. In Ecology of bats: 151-200. Kunz, T.H. (Ed.). New York: Plenum Press.

McNab, B.K. (1989). Temperature regulation and rate of metabolism in three Bornean bats. J. Mammal. 70, 153161.

McNab, B.K. \& Bonaccorso, F.J. (2001). The metabolism of New Guinean pteropodid bats. J. Comp. Physiol. B 171, 201-214.

Menaker, M. (1964). Frequency of spontaneous arousal from hibernation in bats. Nature 203, 540-541.

Millesi, E., Prossinger, H., Dittami, J.P. \& Fieder, M. (2001). Hibernation effects on memory in European ground squirrels (Spermophilus citellus). J. Biol. Rhythms 16, 264 271.

Monadjem, A., Taylor, P.J., Cotterill, F.P.D. \& Schoeman, M.C. (2010). Bats of southern and central Africa: a biogeographic and taxonomic synthesis: Johannesburg: Wits University Press.

Moore, M.S., Reichard, J.D., Murtha, T.D., Nabhan, M.L., Pian, R.E., Ferreira, J.S. \& Kunz, T.H. (2013). Hibernating little brown myotis (Myotis lucifugus) show variable immunological responses to white-nose syndrome. PLOS ONE 8, e58976. 
Morrison, P. (1959). Body temperatures in some Australian mammals. 1. Chiroptera. Biol. Bull. 116, 484- 497.

Munshi-South, J. \& Wilkinson, G.S. (2010). Bats and birds: exceptional longevity despite high metabolic rates. Ageing Res. Rev. 9, 12-19.

Nagy, K.A., Girard, I.A. \& Brown, T.K. (1999). Energetics of free-ranging mammals, reptiles, and birds. Annu. Rev. Nutr. 19, 247-277.

Neuweiler, G. (2000). The biology of bats: New York: Oxford University Press.

Oxberry, B.A. (1979). Female reproductive patterns in hibernating bats. J. Reprod. Fertil. 56, 359-367.

Park, K.J., Jones, G. \& Ransome, R.D. (2000). Torpor, arousal and activity of hibernating greater horseshoe bats (Rhinolophus ferrumequinum). Funct. Ecol. 14, 580-588.

Prendergast, B.J., Freeman, D.A., Zucker, I. \& Nelson, R.J. (2002). Periodic arousal from hibernation is necessary for initiation of immune responses in ground squirrels. Am. J. Physiol. 282, R1054-R1062.

Pretzlaff, I., Kerth, G. \& Dausmann, K.H. (2010). Communally breeding bats use physiological and behavioural adjustments to optimise daily energy expenditure. Naturwissenschaften 97, 353-363.

Racey, P.A. (1973). Environmental factors affecting the length of gestation in heterothermic bats. J. Reprod. Fertil. 19, 175-189.

Racey, P.A. \& Speakman, J.R. (1987). The energy costs of pregnancy and lactation in heterothermic bats. Symp. Zool. Soc. Lond. 57, 107-125.

Rambaldini, D.A. \& Brigham, R.M. (2008). Torpor use by free-ranging pallid bats (Antrozous pallidus) at the northern extent of their range. J. Mammal. 89, 933-941.

Ransome, R.D. (1968). The distribution of the greater horseshoe bat, Rhinolophus ferrumequinum, during hibernation, in relation to environmental factors. J. Zool. (Lond.) 154, 77-112.

Ransome, R.D. (1990). The natural history of hibernating bats: London: Christopher Helm.

Rasweiler, J.J. (1973). Care and management of the longtongued bat, Glossophaga soricina (Chiroptera:

Phyllostomatidae), in the laboratory, with observations on estivation induced by food deprivation. J. Mammal. 54, 391-404.

Reeder, D.M., Frank, C.L., Turner, G.G., Meteyer, C.U., Kurta, A., Britzke, E.R., Vodzak, M.E., Darling, S.R., Stihler, C.W., Hicks, A.C., Jacob, R., Grieneisen, L.E., Brownlee, S.A., Muller, L.K. \& Blehert, D.S. (2012). Frequent arousal from hibernation linked to severity of infection and mortality in bats with white-nose syndrome. PLoS ONE 7, e38920.

Reichard, J.D. \& Kunz, T.H. (2009). White-nose syndrome inflicts lasting injuries to the wings of little brown myotis (Myotis lucifugus). Acta Chiropt. 11, 456-464.

Riek, A., Körtner, G. \& Geiser, F. (2010). Thermobiology, energetics and activity patterns of the Eastern tube-nosed bat (Nyctimene robinsoni) in the Australian tropics: effect of temperature and lunar cycle. J. Exp. Biol. 213, 2557-2564.

Rojas, A.D., Körtner, G. \& Geiser, F. (2012). Cool running: locomotor performance at low body temperature in mammals. Biol. Lett. 8, 868-870.

Schinnerl, M., Aydinonat, D., Schwarzenberger, F. \& Voigt, C.C. (2011). Hematological survey of common neotropical bat species from Costa Rica. J. Zoo Wildl. Med. 42, 382391.

Sedgeley, J.A. (2001). Winter activity in the tree-roosting lesser short-tailed bat, Mystacina tuberculata, in a coldtemperate climate in New Zealand. Acta Chiropt. 3, 179195.

Shen, Y.-Y., Liang, L., Zhu, Z.-H., Zhou, W.-P., Irwin, D.M. \& Zhang, Y.-P. (2010). Adaptive evolution of energy metabolism genes and the origin of flight in bats. Proc. Natl. Acad. Sci. USA 107, 8666-8671.

Solick, D.I. \& Barclay, R.M.R. (2006). Thermoregulation and roosting behaviour of reproductive and nonreproductive female western long-eared bats (Myotis evotis) in the Rocky Mountains of Alberta. Can. J. Zool. 84, 589-599.

Solick, D.I. \& Barclay, R.M.R. (2007). Geographic variation in the use of torpor and roosting behaviour of female western long-eared bats. J. Zool. (Lond.) 272, 358-366.

Speakman, J.R. \& Racey, P.A. (1989). Hibernal ecology of the pipistrelle bat: energy expenditure, water requirements and mass loss, implications for survival and the function of winter emergence flights. J. Anim. Ecol. 58, 797-813.

Speakman, J.R. \& Thomas, D.W. (2003). Physiological ecology and energetics of bats. In Bat ecology: 430-492. Kunz, T.H. \& Fenton, M.B. (Eds). Chicago: University of Chicago Press.

Stawski, C. (2010). Torpor during the reproductive season in a free-ranging subtropical bat, Nyctophilus bifax. J. Therm. Biol. 35, 245-249.

Stawski, C. \& Geiser, F. (2010a). Seasonality of torpor patterns and physiological variables of a free-ranging subtropical bat. J. Exp. Biol. 213, 393-399.

Stawski, C. \& Geiser, F. (2010b). Fat and fed: frequent use of summer torpor in a subtropical bat. Naturwissenschaften 97, 29-35.

Stawski, C. \& Geiser, F. (2011). Do season and distribution affect thermal energetics of a hibernating bat endemic to the tropics and subtropics? Am. J. Physiol. 301, R542R547.

Stawski, C. \& Geiser, F. (2012). Will temperature effects or phenotypic plasticity determine the thermal response of a heterothermic tropical bat to climate change? PLOS ONE 7, e40278.

Stawski, C., Turbill, C. \& Geiser, F. (2009). Hibernation by a free-ranging subtropical bat (Nyctophilus bifax). J. Comp. Physiol. B 179, 433-441.

Stones, R.C. \& Wiebers, J.E. (1965). A review of temperature regulation in bats (Chiroptera). Am. Midl. Nat. 74, 155167. 
Tattersall, G.J., Sinclair, B.J., Withers, P.C., Fields, P.A., Seebacher, F., Cooper, C.E. \& Maloney, S.K. (2012). Coping with thermal challenges: physiological adaptations to environmental temperatures. Compr. Physiol. 2, 21512202.

Teeling, E.C. (2009). Hear, hear: the convergent evolution of echolocation in bats? Trends Ecol. Evol. 24, 351-354.

Teeling, E.C., Springer, M.S., Madsen, O., Bates, P., O’Brien, J. \& Murphy, W.J. (2005). A molecular phylogeny for bats illuminates biogeography and the fossil record. Science 307, 580-584.

Thomas, D.W. \& Geiser, F. (1997). Periodic arousals in hibernating mammals: is evaporative water loss involved? Funct. Ecol. 11, 585-591.

Thomas, D.W., Fenton, M.B. \& Barclay, R.M.R. (1979). Social behaviour of the little brown bat, Myotis lucifugus. Behav. Ecol. Sociobiol. 6, 129-136.

Thompson, A.B., Montiglio, P.O. \& Humphries, M.M. (2013). Behavioural impacts of torpor expression: a transient effect in captive eastern chipmunks (Tamias striatus). Physiol. Behav. 110, 115-121.

Turbill, C. (2006). Thermoregulatory behaviour of treeroosting chocolate wattled bats (Chalinolobus morio) during summer and winter. J. Mammal. 87, 318-323.

Turbill, C. (2008). Winter activity of Australian tree-roosting bats: influence of temperature and climatic patterns. $J$. Zool. (Lond.) 276, 285-290.

Turbill, C. \& Geiser, F. (2006). Thermal physiology of pregnant and lactating female and male long-eared bats, Nyctophilus geoffroyi and N. gouldi. J. Comp. Physiol. B 176, 165-172.

Turbill, C. \& Geiser, F. (2008). Hibernation by tree-roosting bats. J. Comp. Physiol. B 178, 597-605.

Turbill, C., Law, B.S. \& Geiser, F. (2003). Summer torpor in a free-ranging bat from subtropical Australia. J. Therm. Biol. 28, 223-226.

Turbill, C., Körtner, G. \& Geiser, F. (2008). Timing of the daily temperature cycle affects the critical arousal temperature and energy expenditure of lesser long-eared bats. $J$. Exp. Biol. 211, 3871-3878.

Turbill, C., Bieber, C. \& Ruf, T. (2011). Hibernation is associated with increased survival and the evolution of slow life histories among mammals. Proc. Roy. Soc. Lond. Ser. B 278, 3355-3363.

Turmelle, A.S. \& Olival, K.J. (2009). Correlates of viral richness in bats (Order Chiroptera). EcoHealth 6, 522-539.

Twente, J.W. \& Twente, J.A. (1964). A hypothesis concerning the evolution of heterothermy in bats. Ann. Acad. Sci. Fenn. A IV. Biol. 71, 435-442.

Vivier, L. \& van der Merwe, M. (2007). The incidence of torpor in winter and summer in the Angolan free-tailed bat, Mops condylurus (Microchiroptera: Molossidae), in a subtropical environment, Mpumulanga, South Africa. Afr. Zool. 42, 50-58.
Wang, L.-F., Walker, P.J. \& Poon, L.L.M. (2011). Mass extinctions, biodiversity and mitochondrial function: are bats 'special' as reservoirs for emerging viruses? Curr. Opin. Virol. 1, 649-657.

Warnecke, L., Turner, J.M., Bollinger, T.K., Lorch, J.M., Misra, V., Cryan, P.M., Wibbelt, G., Blehert, D.S. \& Willis, C.K.R. (2012). Inoculation of bats with European Geomyces destructans supports the novel pathogen hypothesis for the origin of white-nose syndrome. Proc. Natl. Acad. Sci. USA 109, 6999-7003.

Warnecke, L., Turner, J.M., Bollinger, T.K., Misra, V., Cryan, P.M., Blehert, D.S., Wibbelt, G. \& Willis, C.K.R. (2013). Pathophysiology of white-nose syndrome in bats: a mechanistic model linking wing damage to mortality. Biol. Lett. 9, 20130177.

Wilde, C.J., Kerr, M.A., Knight, C.H. \& Racey, P.A. (1995). Lactation in vespertilionid bats. Symp. Zool. Soc. Lond. 67, 139-149.

Wilkinson, G.S. \& South, J.M. (2002). Life history, ecology and longevity in bats. Aging Cell 1, 124-131.

Willig, M.R., Patterson, B.D. \& Stevens, R.D. (2003). Patterns of range size, richness, and body size in the Chiroptera. In Bat ecology: 430-490. Kunz, T.H. \& Fenton, M.B. (Eds). Chicago: The University of Chicago Press.

Willis, C.K.R. \& Brigham, R.M. (2003). Defining torpor in free-ranging bats: experimental evaluation of external temperature-sensitive radiotransmitters and the concept of active temperature. J. Comp. Physiol. B 173, 379-389.

Willis, C.K.R. \& Brigham, R.M. (2007). Social thermoregulation exerts more influence than microclimate on forest roost preferences by a cavity-dwelling bat. Behav. Ecol. Sociobiol. 62, 97-108.

Willis, C.K.R., Turbill, C. \& Geiser, F. (2005). Torpor and thermal energetics in a tiny Australian vespertilionid, the little forest bat (Vespadelus vulturnus). J. Comp. Physiol. B 175, 479-486.

Willis, C.K.R., Brigham, R.M. \& Geiser, F. (2006). Deep, prolonged torpor by pregnant, free-ranging bats. Naturwissenschaften 93, 80-83.

Willis, C.K.R., Menzies, A.K., Boyles, J.G. \& Wojciechowski, M.S. (2011). Evaporative water loss is a plausible explanation for mortality of bats from white-nose syndrome. Integr. Comp. Biol. 51, 364-373.

Wilson, D.E. \& Reeder, D.M. (2005). Mammal species of the world: Baltimore: Johns Hopkins University Press.

Wojciechowski, M.S., Jefimow, M. \& Tegowska, E. (2007). Environmental conditions, rather than season, determine torpor use and temperature selection in large mouse-eared bats (Myotis myotis). Comp. Biochem. Physiol. A 147, 828840.

Yalden, D.W. \& Morris, P.A. (1975). The lives of bats. New York: Quadrangle/The New York Times Book Co.

Yuan, L., Zhao, X., Lin, B., Rossiter, S.J., He, L., Zuo, X., He, G., Jones, G., Geiser, F. \& Zhang, S. (2011). Adaptive 
evolution of leptin in heterothermic bats. PLOS ONE 6, e27189.

Zhang, G., Cowled, C., Shi, Z., Huang, Z., Bishop-Lilly, K.A., Fang, X., Wynne, J.W., Xiong, Z., Baker, M.L., Zhao, W., Tachedjian, M., Zhu, Y., Zhou, P., Jiang, X.,
Ng, J., Yang, L., Wu, L., Xiao, J., Feng, Y., Chen, Y., Sun, X., Zhang, Y., Marsh, G.A., Crameri, G., Broder, C.C., Frey, K.G., Wang, L.-F. \& Wang, J. (2013). Comparative analysis of bat genomes provides insight into the evolution of flight and immunity. Science 339, 456-460. 